\title{
Composition of gaseous organic carbon during ECOCEM in Beirut, Lebanon: new observational constraints for VOC anthropogenic emission evaluation in the Middle East
}

\author{
Thérèse Salameh $^{1, \mathrm{a}}$, Agnès Borbon ${ }^{1, \mathrm{~b}}$, Charbel $_{\text {Afif }}{ }^{2}$, Stéphane Sauvage $^{3,4}$, Thierry Leonardis ${ }^{3,4}$, Cécile Gaimoz $^{1}$, and \\ Nadine Locoge $\mathbf{e}^{3,4}$ \\ ${ }^{1}$ Laboratoire Interuniversitaire des Systèmes Atmosphériques (LISA), IPSL, CNRS-UMR7583, University of Paris Est \\ Créteil (UPEC) and Paris Diderot (UPD), Créteil, France \\ ${ }^{2}$ Emissions, Measurements, and Modeling of the Atmosphere (EMMA) Laboratory, Unité Environnement, Génomique \\ Fonctionnelle et Études Mathématiques, Centre d'Analyses et de Recherche, Faculty of Sciences, Saint Joseph University, \\ Beirut, Lebanon \\ ${ }^{3}$ Mines Douai, Sciences de l'Atmosphère et Génie de l'Environnement (SAGE), 59508 Douai CEDEX, France \\ ${ }^{4}$ Université de Lille, 59655 Villeneuve d'Ascq, France \\ anow at: Mines Douai, Sciences de l'Atmosphère et Génie de l'Environnement (SAGE), 59508 Douai CEDEX, France \\ bnow at: Laboratoire de Météorologie Physique (LaMP), CNRS-UMR 6016, University of Blaise Pascal, \\ Clermont-Ferrand, France
}

Correspondence to: Thérèse Salameh (salameh.therese@gmail.com)

Received: 21 June 2016 - Published in Atmos. Chem. Phys. Discuss.: 5 August 2016

Revised: 11 November 2016 - Accepted: 26 November 2016 - Published: 4 January 2017

\begin{abstract}
The relative importance of eastern Mediterranean emissions is suspected to be largely underestimated compared to other regions worldwide. Here we use detailed speciated measurements of volatile organic compounds (VOCs) to evaluate the spatial heterogeneity of VOC urban emission composition and the consistency of regional and global emission inventories downscaled to Lebanon (European Monitoring and Evaluation Programme, EMEP; Atmospheric Chemistry and Climate Model Intercomparison Project, ACCMIP; and MACCity, Monitoring Atmospheric Composition and Climate and megaCITY Zoom for the Environment). The assessment was conducted through the comparison of the emission ratios (ERs) extracted from the emission inventories to the ones obtained from the hourly observations collected at a suburban site in Beirut, Lebanon, during summer and winter ECOCEM (Emissions and Chemistry of Organic Carbon in the Eastern Mediterranean) campaigns. The observed ERs were calculated using two independent methods. ER values from both methods agree very well and are comparable to the ones of the road transport sector from near-field measurements for more than $80 \%$ of the species. There is no significant seasonality in ER for more than $90 \%$ of the species,
\end{abstract}

unlike the seasonality usually observed in other cities worldwide. Regardless of the season, ERs agree within a factor of 2 between Beirut and other representative cities worldwide, except for the unburned fuel fraction and ethane. ERs of aromatics (except benzene) are higher in Beirut compared to northern post-industrialized countries and even the Middle Eastern city Mecca. The comparison of the observed ER to the ones extracted from the ACCMIP and MACCity global emission inventories suggests that the overall speciation of anthropogenic sources for major hydrocarbons that act as ozone and secondary organic aerosol (SOA) precursors in ACCMIP is better represented than other species.

The comparison of the specific road transport ERs, relative to acetylene derived from near-field measurements, to ERs from ACCMIP and EMEP emission inventories for the road transport sector showed that ERs of more reactive species are usually consistent within a factor of 2 with EMEP, while xylenes and toluene are underestimated by over a factor of 2 by ACCMIP.

The observed heterogeneity of anthropogenic VOC emission composition between Middle Eastern cities can be significant for reactive VOCs but is not depicted by global emis- 
sion inventories. This suggests that systematic and detailed measurements are needed in the eastern Mediterranean Basin in order to better constrain emission inventory.

\section{Introduction}

In the context of global climate change and growing urbanization, the eastern Mediterranean Basin (EMB), and the Middle East as a whole, is a highly sensitive environment under considerable anthropogenic and environmental pressures. Future decadal projections point to the EMB as a possible hotspot of poor air quality and predict a continual and gradual warming in the region, much stronger than in other regions (Gurjar et al., 2008; Lelieveld et al., 2012, 2015; Pozzer et al., 2012). The increase and accumulation of anthropogenic emissions of gaseous and particulate pollutants from surrounding urban areas, and on-road transport emissions in particular, are suspected as two of the key compounding factors of those environmental impacts (Konovalov et al., 2010; von Schneidemesser et al., 2010; Waked and Afif, 2012; Hillboll et al., 2013). The EMB area includes two megacities: Istanbul (>12 million inhabitants) and Cairo (> 15 million inhabitants), which experience extremely high levels of pollution (Kanakidou et al., 2011). Satellite images of $\mathrm{NO}_{2}$ columns from SCIAMACHY also point to the coastal urban areas of the Middle East as important hotspots of pollution in the region (Lelieveld et al., 2009).

Trend analysis from satellite and ground-based observations found decreasing trends of primary pollutants in western Europe and increasing trends from hydrocarbon groundbased observations and $\mathrm{NO}_{x}$ satellite retrievals in other regions (Konovalov et al., 2010; von Schneidemesser et al., 2010). Downward trends in pollutant emissions are a shared feature of northern mid-latitude urban areas. The mixing ratios of volatile organic compounds (VOCs) and CO (carbon monoxide) have decreased by almost 2 orders of magnitude during the past 5 decades in Los Angeles (Warneke et al., 2012). In the UK, long-term trends show significant decreases for VOCs reaching $26 \%$ per year as well as up to $12 \%$ for CO per year (von Schneidemesser et al., 2010). Indeed, vehicle exhaust emission control has successfully reduced emissions of nitrogen oxides, carbon monoxide, volatile organic compounds, and particulate matter (Uherek et al., 2010). In developing countries however, pollutant emissions have been growing strongly. Waked and Afif (2012) showed that the emissions of CO rapidly increased by a factor of 2.8 in the countries of the Middle East between 2000 and 2005 as a result of the increase in fuel consumption. They also found that the road transport sector in the Middle East is as significant of a contributor to the global emissions of $\mathrm{CO}$ and $\mathrm{NO}_{x}$ as road transport in western Europe and North America. These findings are consistent with results reported by Uherek et al. (2010) for a larger range

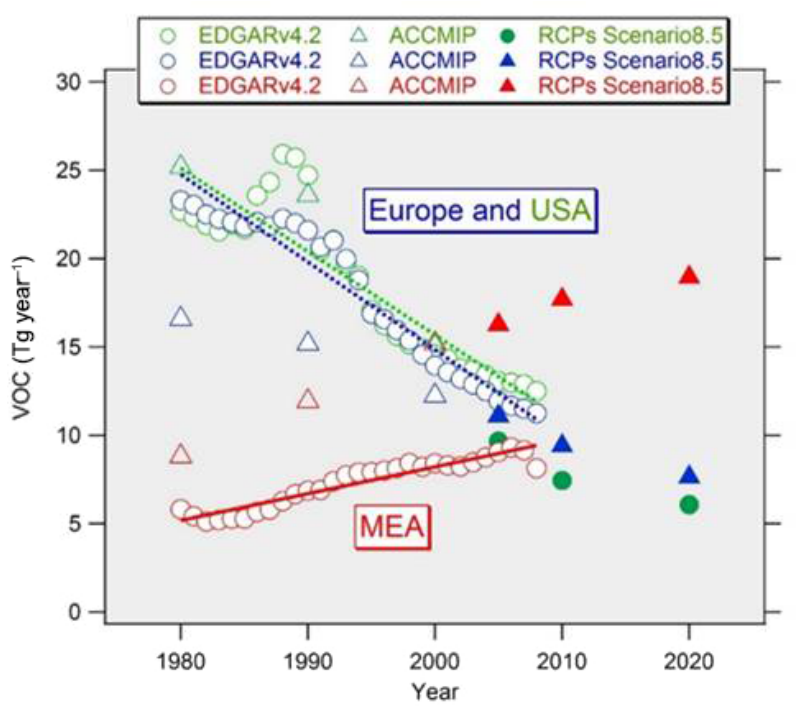

Figure 1. Evolution of the NMVOC anthropogenic total emissions $\left(\right.$ Tg year $^{-1}$ ) in the MEA, USA, and Europe (OECD (Organisation for Economic Co-operation and Development) Europe and eastern Europe) from 1980 to 2020 from reference global emission inventories (ECCAD database).

of pollutants $\left(\mathrm{CO}_{2}, \mathrm{CO}, \mathrm{NO}_{x}\right.$, and NMVOCs, non-methane volatile organic compounds).

The same picture is presented by emission inventories. Figure 1 compares the annual total anthropogenic emissions of NMVOCs from three reference emission inventories between the Middle Eastern (MEA) region, Europe, and North America: ACCMIP (Atmospheric Chemistry and Climate Model Intercomparison Project), EDGARv4.2 (Emissions Database for Global Atmospheric Research), and RCPs (Representative Concentrations Pathways) (ECCAD, 2015, http://eccad.sedoo.fr). NMVOC emissions have been constantly increasing in the MEA region over the last 30 years, reaching up to $18 \mathrm{Tg}_{\text {gear }}{ }^{-1}$ according to RCP 8.5 in 2010 . In contrast, the NMVOC emissions have been strongly decreasing in the USA and Europe, with totals of 7 and $10 \mathrm{Tg}_{\mathrm{gear}}{ }^{-1}$ in 2010 respectively according to RCP 8.5 (Fig. 1). While differences up to a factor of 2 can be found between ACCMIP and EDGARv4.2 for the MEA in 2000 (Fig. 1), all inventories suggest that NMVOC emissions from the MEA region are as significant as or even higher than the ones from post-industrialized regions. Finally, no source regions clearly dominate global anthropogenic emissions, and therefore an accurate representation of anthropogenic emissions in developing regions like the MEA where highest uncertainties are expected is of importance.

The quantification of emission distribution is a challenge, and even more so in cities of the EMB, and the Middle East as a whole, where local emission data are sparse. Indeed, emission inventories usually combine bottom-up and top-down calculations to estimate emissions. Comprehensive bottom- 
up calculations aggregate multiple local statistics on different emission source categories where possible. Top-down calculations use regional or national activity data and reallocate emissions to a finer scale using spatial surrogates (e.g. population statistics at the local level). Therefore, the uncertainties of numerous data sources are cumulated in the overall estimation of emission amounts and along increasing scales (local to regional to global). Granier et al. (2011) assessed the evolution of anthropogenic and biomass burning emissions of $\mathrm{CO}, \mathrm{NO}_{x}, \mathrm{SO}_{2}$, and $\mathrm{BC}$ at global and regional scales from several inventories during the 1980-2010 period and concluded that there is still no consensus on the best estimates for surface emissions of atmospheric compounds (Granier et al., 2011).

Several studies in the literature have reported evaluations of emission inventories in developed countries using ambient pollutant observations at ground level, on-board aircraft, and from satellite retrievals (Martin et al., 2003; Kim et al., 2011). For instance, urban emission ratios of various VOCs relative to a tracer of incomplete combustion ( $\mathrm{CO}$, acetylene) have been used as high-quality field constraints to evaluate regional emission inventories in cities of post-industrialized countries (Warneke et al., 2007; Coll et al., 2010; Borbon et al., 2013). The most recent diagnostic studies reveal large discrepancies between observations and inventories as large as a factor 4 for VOCs in Paris and Los Angeles, for instance (Borbon et al., 2013). In situ observations are therefore necessary constraints for the development of reliable emission inventories. Moreover, they also provide direct indications of air pollution exposure. While some highly resolved inventories have been developed at the regional scale in the EMB area for Beirut (Waked et al., 2012) and Istanbul (Im at al., 2011; Markakis et al., 2012), their uncertainties are unknown and speciation of NMVOC is usually disregarded. For solely Lebanon, the atmospheric emission inventory of anthropogenic and biogenic sources was established by Waked et al. (2012) for a base year of 2010 for $\mathrm{CO}, \mathrm{NO}_{x}$, $\mathrm{SO}_{2}$, total NMVOCs, $\mathrm{NH}_{3}, \mathrm{PM}_{10}$, and $\mathrm{PM}_{2.5}$, according to European Environment Agency - European Monitoring and Evaluation Programme guidelines (EMEP/EEA, 2009). The NMVOC total emissions in Lebanon were estimated to be $115 \mathrm{Gg}$ for the year 2010. According to this inventory, transport is the main source of NMVOC, with a relative contribution of $67 \%$ of total emissions of NMVOCs (Waked et al., 2012). In addition, there is a strong need for developing better emission inventories in the Middle East as a whole (Waked et al., 2013). The paucity of observations in this region, especially for VOCs and PM composition, is a significant limitation to the achievement of evaluated and accurate emission inventories. Finally, accurate modelling of individual NMVOCs and better understanding of ozone precursors is also important for policymakers and for the improvement of air quality, leading to better estimates of secondary organic aerosol (SOA) formation and ozone levels.
The present paper aims to evaluate global VOC speciated emission inventories, in the absence of regional emission inventories for MEA, by using detailed observations recently collected in Beirut, Lebanon, in the frame of the ECOCEM project (Emissions and Chemistry of Organic Carbon in the Eastern Mediterranean) (Salameh et al., 2015). Those observations include detailed near-source field measurements and ambient measurements at a suburban site. We used regional (EMEP) and global (ACCMIP and MACCity) emission inventories downscaled to Lebanon. Two independent methods already applied to the Los Angeles basin during the CalNex experiment (Borbon et al., 2013), which take into consideration the effects of chemical removal, were used to estimate the urban enhancement emission ratios (ERs) of various NMVOCs relative to $\mathrm{CO}$ and acetylene for winter and summer. First, calculated ERs are compared to available ERs in other cities worldwide in order to assess the spatial variability of emission composition. Second, calculated ERs are compared to the ones derived from global emission inventories for all the anthropogenic sectors and for the road transport sector. Finally, perspectives for the whole Middle Eastern region are discussed.

\section{Experiment}

The experimental strategy includes near-field measurements close to major emission sources and two intensive field campaigns conducted in summer 2011 and in winter 2012 in Beirut at a suburban site, within the ECOCEM project. VOCs have been measured by a combination of online and offline techniques (Table 1). A set of eight speciated profiles of four major non-methane hydrocarbon (NMHC) sources in Lebanon were proposed by Salameh et al. (2014) by sampling close to emission sources in real-world operating conditions as far as possible. Field sampling was carried out in Beirut and its suburban area during March and April 2012. The sampling was performed using canisters and the analyses were performed in the laboratory using the thermal desorption-gas chromatography (TD-GC) technique coupled to a flame ionization detector (FID) from Perkin-Elmer (Salameh et al., 2014, 2015).

The field campaigns were conducted on the roof of the Faculty of Sciences building of Saint Joseph University located in the eastern suburbs of Beirut from 2 to 18 July 2011 in summer and from 28 January to 12 February 2012 in winter. The site is appropriately located in order to receive air masses coming from the greater Beirut area, which includes the city of Beirut and close suburbs. The site is surrounded by a forested pine, high-density residential area. Beirut International Airport is located $8 \mathrm{~km}$ southwest of the site and one fuel storage facility is located at $3.6 \mathrm{~km}$ north. More details are reported in Salameh et al. (2015). During both measurement periods, NMHCs were continuously analysed on an hourly basis covering $30 \mathrm{~min}$ of ambient air sampling us- 
Table 1. Measurements during ECOCEM campaigns.

\begin{tabular}{|c|c|c|c|c|}
\hline Species & Instrument & Time resolution & Performances & References \\
\hline \multicolumn{5}{|l|}{ Online } \\
\hline $\begin{array}{l}67 \text { C2-C9 NMHC } \\
29 \text { alkanes } \\
19 \text { alkenes } \\
2 \text { alkynes } \\
17 \text { aromatics }\end{array}$ & TD-GC-FID & $1 \mathrm{~h}$ & $\begin{array}{l}\text { DL: } 40-90 \mathrm{ppt}, \\
\text { uncertainty: } 4-35 \% \\
\text { for the majority of } \\
\text { the NMHCs }\end{array}$ & $\begin{array}{l}\text { Salameh et al. (2014, } \\
\text { 2016) }\end{array}$ \\
\hline \multicolumn{5}{|l|}{ Off-line } \\
\hline 67 C2-C9 NMHC & $\begin{array}{l}\text { Canister/ } \\
\text { TD-GC-FID }\end{array}$ & $\begin{array}{l}\text { Sampling }<3 \mathrm{~min} / \\
1 \mathrm{~h} \text { analysis }\end{array}$ & $\begin{array}{l}\text { DL: } 40-90 \mathrm{ppt}, \\
\text { uncertainty: } 15 \%\end{array}$ & $\begin{array}{l}\text { Salameh et al. (2014), } \\
\text { Sauvage et al. (2009) }\end{array}$ \\
\hline
\end{tabular}

ing the same system (TD-GC-FID) used for canister analysis. Additional measurements of trace gas concentrations, including $\mathrm{CO}, \mathrm{NO}_{x}$, and $\mathrm{O}_{3}$, were provided on a 1 min basis by specific analysers. Basic meteorological parameters (wind speed and direction, temperature, relative humidity, and atmospheric pressure) were measured on a $1 \mathrm{~min}$ basis for the duration of the campaigns.

During the summer field campaign, the average temperature was around $25 \pm 2{ }^{\circ} \mathrm{C}$ and the average wind speed was low, $2 \mathrm{~m} \mathrm{~s}^{-1}$, with maximum wind speeds $\left(4-10 \mathrm{~m} \mathrm{~s}^{-1}\right)$ recorded during the days under southwestern wind regimes and under northern wind regimes. During the winter measurement campaign, the temperature stayed mild with an average of $13 \pm 2{ }^{\circ} \mathrm{C}$. The average wind speed was still low at $2 \mathrm{~m} \mathrm{~s}^{-1}$, and the wind direction was mostly southeasterly and easterly.

\section{Regional and global emission database}

At the global and the regional scales, several emission inventories were developed over the past few years in order to provide the distribution of surface emissions of different gaseous and particulate compounds.

The EMEP regional emission inventory covers the period from 1980 to 2020 at a $0.5^{\circ}$ resolution. It contains national total emissions for Europe and sector data and gridded emission data for modelling purposes. The sectors follow the SNAP categorization (Selected Nomenclature for reporting of Air Pollutants). Only the emissions regarding road transport (SNAP 07) are included in this study.

Since there is no global emissions dataset available after 2000, the MACCity emissions have been developed within two European Commission funded projects (MACC and CityZen) as an extension of the ACCMIP and the RCP 8.5 emissions dataset. The emissions for each compound were then linearly interpolated for each sector and each year between 2000 and 2010. A seasonal cycle was applied for each sector, and the NMVOC species anthropogenic emissions were lumped into 13 species (excluding acetylene) using the same methodology for the NMVOC speciation as used in the ACCMIP dataset.

A large number of emission inventories only provide the distribution of total NMVOC emissions by lumping organic species (alkanes, alkenes, alkynes, alcohols, aldehydes, ketones, and aromatic compounds) for chemistry modelling purposes (EDGARv4.2, ECLIPSE-GAINS-4a). We rely on the ACCMIP inventory from the ECCAD (Emissions of Atmospheric Compounds and Compilation of Ancillary Data) database, which provides a detailed speciation of VOCs, including acetylene. The ACCMIP global emission inventory covers the historical period (1850-2000) in decadal increments at a horizontal resolution of $0.5^{\circ}$ in latitude and longitude, based on the combination of the best global and regional available datasets. ACCMIP was developed mainly to provide consistent gridded emissions of reactive gases and aerosols for use in chemistry model simulations needed by climate models for the Climate Model Intercomparison Program 5 (CMIP5) in support of the Intergovernmental Panel on Climate Change (IPCC) Fifth Assessment report (AR5) (Lamarque et al., 2010). To combine the various sources within this inventory, 40 regions and 12 sectors were used, and a set of species including $\mathrm{CO}, \mathrm{NO}_{x}$, and total and speciated NMVOCs is provided. Speciation of NMVOC emissions is performed using the RETRO (REanalysis of the TROpospheric chemical composition) (Schultz et al., 2007) inventory and is kept constant for the whole historical period because of the lack of additional information. For all NMVOC species of the RETRO inventory, a factor was calculated only for the year 2000 by dividing the emission of each individual species by the total NMVOC anthropogenic emissions for each sector in each grid cell.

For comparison with observations, we extracted the emission fluxes $\left(\mathrm{kg} \mathrm{m}^{-2} \mathrm{~s}^{-1}\right)$ of 11 individual NMVOCs as well as the $\mathrm{CO}$ of eight grids covering Lebanon surface area (ECCAD database). Target sectors cover all anthropogenic sectors and the transport sector for 2000. Since the flux of the eight grids is spatially homogeneous for all compounds, we calculated a mean flux for each NMVOC to derive the 


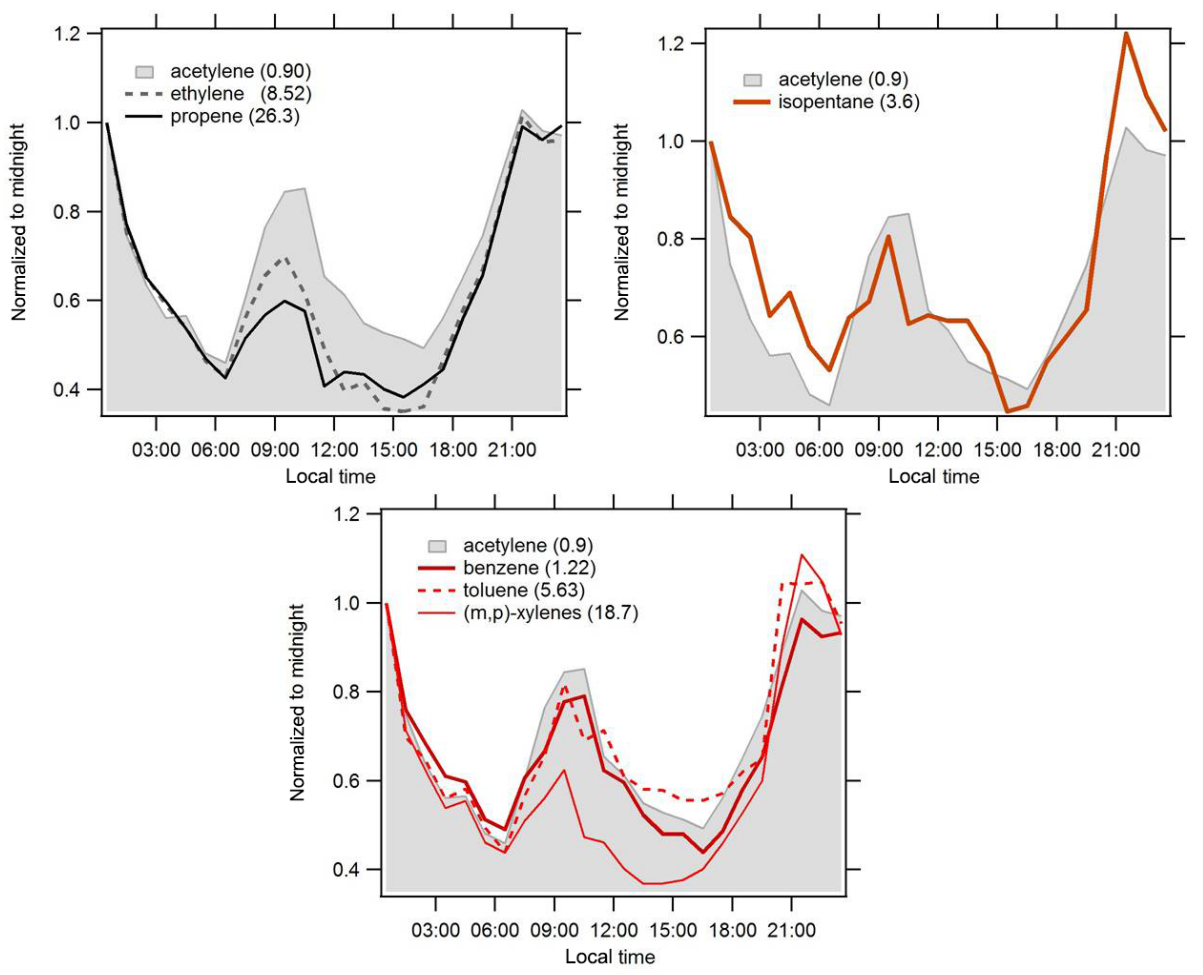

Figure 2. Normalized diurnal profiles of the mixing ratio of selected species to midnight values in summer. Numbers in parentheses are the rate coefficient with $\mathrm{OH} \times 10^{-12} \mathrm{~cm}^{3}$ molecule ${ }^{-1} \mathrm{~s}^{-1}$ (Atkinson and Arey, 2003; Atkinson, 2007).

emission ratio from the inventory. Comparing emission ratios from the inventory to observations collected at one measurement site stays relevant. Indeed, the suburban site is far enough from strong direct emissions (industrial, road transport) since they can hide the emissions from distant sources, and it receives air masses coming from the greater Beirut area, which includes the city of Beirut and close suburbs.

\section{Emission and chemistry of gaseous organic carbon in Beirut on a seasonal basis}

The intensity of the emissions, chemistry, and atmospheric dynamics varying throughout the day can affect the diurnal profiles of NMVOC absolute mixing ratios and, as a consequence, the values of urban enhancement ERs (see Sect. 5). We report in Figs. 2 and 3 for summer and winter respectively the average diurnal normalized profiles for the midnight value of some NMVOCs, relative to a tracer, to examine the relative importance of these processes (Borbon et al., 2013). Acetylene was chosen as a less-reactive combustion tracer and its normalized diurnal profile is reported in each panel (grey, shaded). The extremely high NMVOC concentrations were filtered by removing the northern wind direction events, referring to the identified gasoline evaporation episodic PMF (positive matrix factorization) factor (Salameh et al., 2016), in order to minimize the impact of the local industrial source located in the northern part of the site (Salameh et al., 2015, 2016).

In summer all NMHCs, including acetylene, show the same bimodal pattern, with one midday and one midnight maximum, as a result of primary emissions from greater Beirut transported to the background receptor site between 09:00 and 10:00 LT (local time) and accumulation of emissions at night in a shallower boundary layer. The degree of chemical removal during the day is $k_{\mathrm{OH}^{-}}$dependent $\left(k_{\mathrm{OH}}\right.$ is the rate coefficient for the reaction with $\mathrm{OH}$ ) and increases with $k_{\mathrm{OH}}$ as illustrated for alkenes and aromatics. At night alkenes and aromatics follow the pattern of acetylene due to common sources, dilution, and less photochemistry. Then the importance of daytime maximum and minimum concentration becomes modulated by chemical removal when $k_{\mathrm{OH}}$ is higher than $8.52 \times 10^{-12} \mathrm{~cm}^{3}$ molecule ${ }^{-1} \mathrm{~s}^{-1}$ (rate coefficient of ethylene with $\mathrm{OH}$ ). Compensation of chemical removal at midday by fresh evaporative emissions cannot be excluded for aromatics like toluene.

In winter the diurnal profiles of NMHCs, including acetylene, show a unimodal pattern characterized by maximum concentrations in the morning, typical of traffic rush hours, and a slight decrease until late evening. Contrary to summer, the absence of a midday minimum of normalized concentrations indicates a strong accumulation of primary emissions during the day, which is favoured by poor dilution and negligible photochemistry. However, the diurnal profiles 

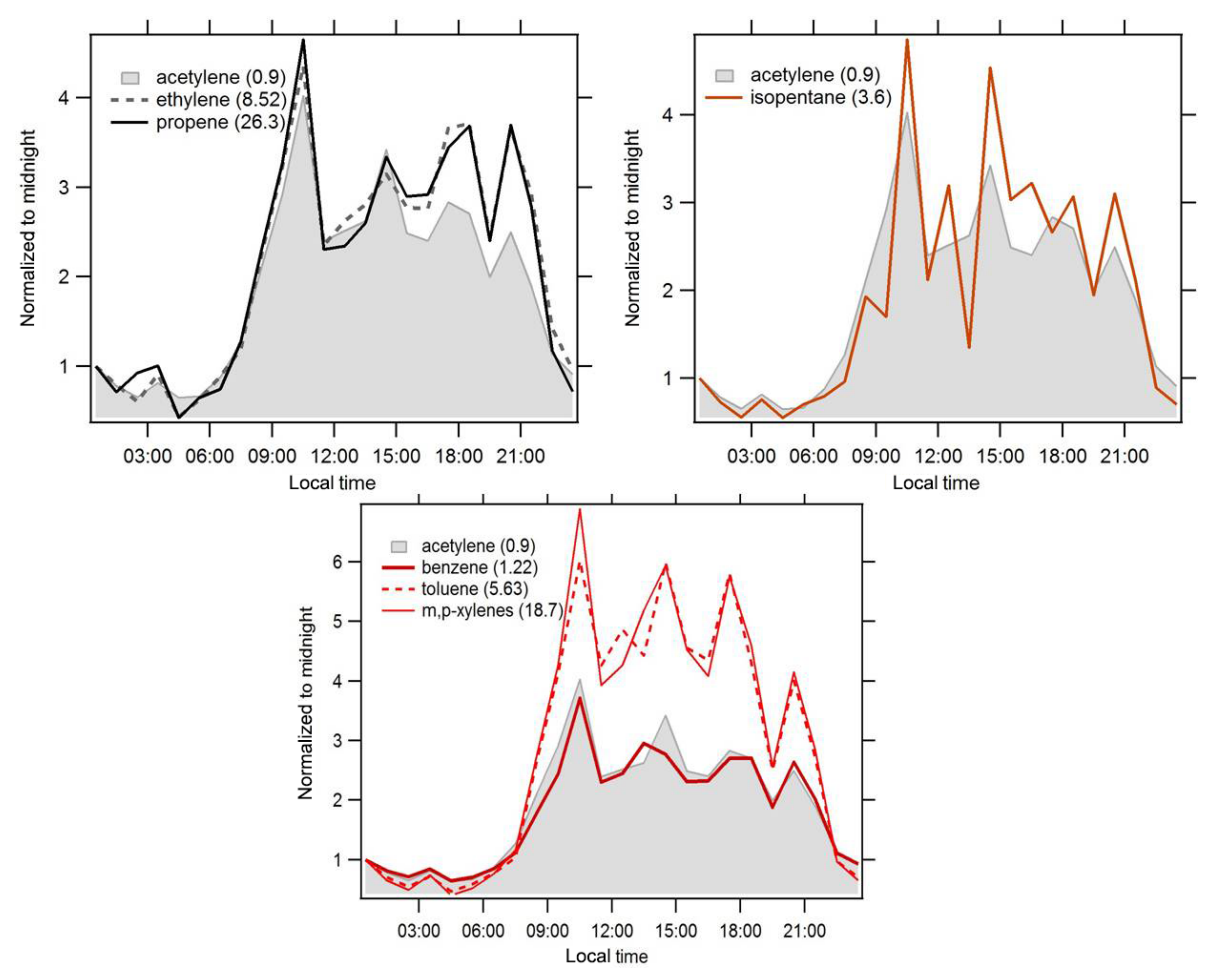

Figure 3. Normalized diurnal profiles of the mixing ratios of selected species to midnight values in winter. Numbers in parentheses are the rate coefficient with $\mathrm{OH} \times 10^{-12} \mathrm{~cm}^{3}$ molecule $\mathrm{s}^{-1}$ (Atkinson and Arey, 2003; Atkinson, 2007).

of alkenes illustrated in Fig. 3 are characterized by a most pronounced enhancement in the evening, which can be related to additional combustion sources like domestic heating since the measurement site is surrounded by a residential area (Salameh et al., 2015). Aromatic and alkane diurnal profiles follow the shape of the acetylene profile in general. Nevertheless, one can see a strong enrichment of aromatics during the day, originating from the traffic-related source where toluene and $\mathrm{m}, \mathrm{p}$-xylenes are significantly present (Watson et al., 2001; Badol et al., 2008; Salameh et al., 2016).

In this section, we showed that some NMHCs, especially shorter-lived species like $>\mathrm{C} 7$ aromatics, ethylene, and propene, could be affected by chemical removal in summer so that the measured urban enhancement ratios can be different from the emission ratios. These results are consistent with Salameh et al. (2015). The determination of ERs in the next section will take into account the potential effect of chemistry by applying temporal filters for the most reactive species in summer. When NMHCs are not influenced by photochemistry, the enhancement ratios will be estimated using all the data.

\section{Determination of urban enhancement emission ratios}

The emission ratio for NMVOC species is the ratio of a selected VOC to a reference compound in fresh emissions without undergoing photochemical processing. We applied two methods to determine ERs for each VOC species relative to $\mathrm{CO}$ and acetylene. The first method consists of linear regression fits (LRFs) on data applied to summer and winter datasets, and the other method relies on extrapolating the photochemical age to zero, which was applied to the summer data (photochemical removal is negligible in winter).

\subsection{Linear regression fit (LRF) method}

A commonly applied method to determine emission ratios is the linear regression fit (LRF), which calculates the slope of the scatter plot between a particular NMVOC vs. acetylene or CO (Borbon et al., 2013). These reference compounds were chosen due to their low reactivity and since they are two tracers of incomplete combustion. Additionally, according to the national emission inventory (Waked et al., 2012) and PMF results (Salameh et al., 2016), road transport is the dominant source of NMVOCs in Lebanon and greater Beirut; in urban areas as well, emissions of $\mathrm{CO}$ are also dominated by vehicular emissions (von Schneidemesser et al., 2010).

During both campaigns, as shown in the discussion in Sect. 4, photochemical processing did not play an important role in influencing NMVOC chemical compositions in the ambient air of greater Beirut, except for the most reactive species during the day in summer (alkenes and aromatics). For the latter, NMVOC:CO and NMVOC: acetylene 
ERs were derived from slopes of LRF for measurements made between 23:00 and 07:00 LT in summer when chemistry can be neglected. For isoprene, anthropogenic emissions can be derived from night-time data in the absence of its light-dependent biogenic origin (Borbon et al., 2001). The LRF approach assumes that the composition of urban emissions relative to $\mathrm{CO}$ and to acetylene does not change between day and night. For other species, the emission ratios were derived from slopes of LRF for all the data in winter and summer since there is no effect of photochemistry even during the day in summer and in order to cover the urban mixing of emissions from all the sources. The results are detailed in Sect. 5.4 and summarized in Table 2.

\subsection{The photochemical age method}

The photochemical method takes into consideration the photochemical processing of measured ratios of NMVOC with acetylene. We applied this method to the entire summer dataset. Following de Gouw et al. (2005), Warneke et al. (2007), and Borbon et al. (2013), we assume that the photochemical removal of NMVOC species is dominated by a reaction with the $\mathrm{OH}$ radical. In this method, the ratio of NMVOC to acetylene is plotted vs. the photochemical age, as shown in Fig. 4.

The photochemical age of air masses, $\Delta t$, is estimated by using the NMVOC ratios using the following equation:

$$
\begin{aligned}
\Delta t= & \frac{1}{[\mathrm{OH}]\left(k_{135 \mathrm{TMB}}-k_{\text {benzene }}\right)} \\
& \times\left[\ln \left(\frac{[135 \mathrm{TMB}]}{[\text { benzene }]}\right)_{t=0}-\ln \left(\frac{[135 \mathrm{TMB}]}{[\text { benzene }]}\right)\right],
\end{aligned}
$$

where $[\mathrm{OH}]$ is the concentration of hydroxyl radicals, fixed to $5 \times 10^{6} \mathrm{molec} \mathrm{cm}^{-3} ; \quad k_{135 \mathrm{TMB}}$ $\left(56.7 \times 10^{-12} \mathrm{~cm}^{3} \mathrm{molec}^{-1} \mathrm{~s}^{-1}\right) \quad$ and $\quad k_{\text {benzene }}$ $\left(1.22 \times 10^{-12} \mathrm{~cm}^{3} \mathrm{molec}^{-1} \mathrm{~s}^{-1}\right)$ are the reaction rate coefficients with an $\mathrm{OH}$ radical of 1,3,5-trimethylbenzene and benzene, respectively; [135TMB] and [benzene] are the volume mixing ratios in ppb of benzene and 1,3,5-trimethylbenzene, respectively. The 1,3,5-trimethylbenzene / benzene ratio was chosen to investigate the photochemical age because these two compounds have similar sources but their lifetimes are significantly different and lower than the air mass transport timescale. The ratio of [135TMB] to [benzene] at time zero $(t=0)$ defines the emission ratio at a photochemical age of zero. This emission ratio was derived from a scatter plot of [135TMB] vs. [benzene], and it corresponds to the emission enhancement ratio of night-time data where photochemical processing can be neglected.

In Fig. 4, we report the ratios of measured benzene / acetylene, m,p-xylenes / acetylene, and ethylene / acetylene as a function of the photochemical age. Calculated photochemical age is usually lower than $1 \mathrm{~h}$. As expected, the benzene/acetylene ratio remains constant with increasing photochemical age, whereas a decrease of

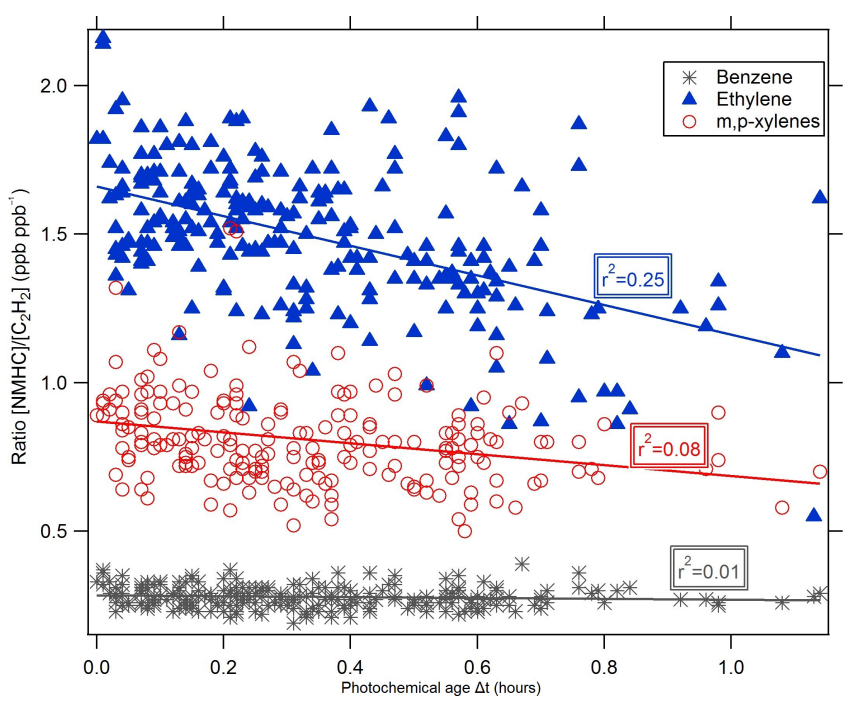

Figure 4. Measured ratios of benzene/acetylene, m,pxylenes / acetylene, and ethylene/acetylene as a function of photochemical age $(h)$.

m,p-xylenes / acetylene and ethylene / acetylene ratios is observed because they are more reactive. Surprisingly, the ethylene / acetylene ratio decreases faster than the (m,p)xylenes / acetylene ratio since (m,p)-xylenes are 2 times more reactive than ethylene. The decrease of the $(\mathrm{m}, \mathrm{p})$ xylenes / acetylene ratio might be modulated by additional evaporative emissions during the day that counterbalance its chemical removal.

Following de Gouw et al. (2005) and Warneke et al. (2007), the equation used for emission ratio determination illustrated in Fig. 4 is described as follows for primary NMHCs (Eq. 2):

$$
\begin{aligned}
\frac{[\mathrm{NMVOC}]}{\left[\mathrm{C}_{2} \mathrm{H}_{2}\right]}= & \mathrm{ER}_{\mathrm{NMVOC}} \\
& \times \exp \left[-\left(k_{\mathrm{NMVOC}}-k_{\mathrm{C}_{2} \mathrm{H}_{2}}\right)[\mathrm{OH}] \Delta t\right],
\end{aligned}
$$

where [NMVOC] and $\left[\mathrm{C}_{2} \mathrm{H}_{2}\right]$ are the volume mixing ratios in ppb of NMVOCs and acetylene respectively, $\mathrm{ER}_{\mathrm{NMVOC}}$ is the emission ratio of the NMVOC relative to acetylene; $k_{\mathrm{NMVOC}}$ and $k_{\mathrm{C}_{2} \mathrm{H}_{2}}$ are the OH-rate coefficients for the reaction of those compounds with $\mathrm{OH}$ radical $([\mathrm{OH}]=5 \times$ $10^{6}$ molecules $\mathrm{cm}^{-3}$ ), and $\Delta t$ is the photochemical age calculated by Eq. (1). The emission ratios of NMVOCs are estimated by extrapolating the photochemical age to zero, which is the intercept on the y-axis of the linear fit (Fig. 4).

Following Borbon et al. (2013) and Warneke et al. (2007), the emission ratios determined with the photochemical age method are not affected when reducing or increasing the $\mathrm{OH}$ values by a factor of 2 . 
Table 2. Urban emission ratios of VOCs relative to acetylene and CO in Beirut in summer and in winter, obtained by calculating a linear regression fit to data. The ERs from road transport by near-field measurements are also reported. Bold characters indicate the similarity at $\pm 50 \%$ of the VOC: acetylene ER from the measurement campaigns to the one of near-field measurements.

\begin{tabular}{|c|c|c|c|c|}
\hline \multirow[b]{2}{*}{ NMVOC } & \multicolumn{3}{|c|}{$\Delta \mathrm{VOC} / \Delta \mathrm{C}_{2} \mathrm{H}_{2}(\mathrm{ppb} / \mathrm{ppb})$} & \multirow{2}{*}{$\begin{array}{r}\begin{array}{r}\Delta \mathrm{VOC} / \Delta \mathrm{CO} \\
(\mathrm{ppb} / \mathrm{ppm})\end{array} \\
\text { Beirut - } \\
\text { winter } 2012\end{array}$} \\
\hline & $\begin{array}{l}\text { Beirut - } \\
\text { summer } \\
2011\end{array}$ & $\begin{array}{r}\text { Beirut - } \\
\text { winter } \\
2012\end{array}$ & $\begin{array}{r}\text { Road transport and near-field } \\
\text { spring } 2012 \text { measurement } \\
\text { (Salameh et al., 2014) }\end{array}$ & \\
\hline ethane & 0.23 & 0.18 & 0.21 & 1.50 \\
\hline propane & 1.02 & 0.58 & 0.21 & 5.40 \\
\hline n-butane & 1.14 & 0.95 & 1.87 & 6.70 \\
\hline i-butane & 0.25 & 0.48 & 0.72 & 3.30 \\
\hline n-pentane & 0.26 & 0.15 & 0.40 & 1.10 \\
\hline i-pentane & 1.22 & 0.75 & 1.77 & 5.30 \\
\hline 2-methyl-pentane & 0.29 & 0.18 & 0.30 & 1.20 \\
\hline 3-methyl-pentane & 0.17 & 0.11 & 0.16 & 0.80 \\
\hline 2,2-dimethylbutane & 0.10 & 0.03 & 0.11 & 0.20 \\
\hline n-hexane & 0.11 & 0.10 & 0.10 & 0.90 \\
\hline Methylcyclopentane & 0.13 & 0.11 & 0.06 & 0.90 \\
\hline 2-methyl-hexane & 0.11 & 0.08 & 0.08 & 0.70 \\
\hline 3-methyl-hexane & 0.11 & 0.09 & 0.09 & 0.70 \\
\hline cyclohexane & 0.04 & 0.01 & 0.01 & 0.10 \\
\hline n-heptane & 0.07 & 0.05 & 0.06 & 0.40 \\
\hline 2,3-dimethylpentane & 0.04 & 0.03 & 0.03 & 0.20 \\
\hline Methylcyclohexane & 0.04 & 0.03 & 0.03 & 0.20 \\
\hline 3-methyl-heptane & 0.03 & 0.02 & 0.02 & 0.20 \\
\hline n-octane & 0.04 & 0.02 & 0.02 & 0.20 \\
\hline 2,2,4-trimethylpentane & 0.17 & 0.13 & 0.19 & 1.00 \\
\hline 2,3,4-trimethylpentane & 0.06 & 0.04 & 0.08 & 0.30 \\
\hline n-nonane & 0.04 & 0.03 & 0.01 & 0.20 \\
\hline acetylene & - & - & - & 8.20 \\
\hline propyne & 0.05 & 0.04 & 0.04 & 0.40 \\
\hline ethene & 1.59 & 1.02 & 0.97 & 9.30 \\
\hline propene & 0.47 & 0.32 & 0.31 & 3.00 \\
\hline 1-butene & 0.10 & 0.09 & 0.20 & 0.70 \\
\hline cis-2-butene & 0.13 & 0.08 & 0.15 & 0.60 \\
\hline trans-2-butene & 0.16 & 0.11 & 0.19 & 0.90 \\
\hline isobutene & 0.17 & 0.12 & 0.42 & 1.00 \\
\hline 3-methyl-1-butene & 0.03 & 0.02 & 0.05 & 0.10 \\
\hline 2-methyl-1-butene & 0.09 & 0.06 & 0.15 & 0.40 \\
\hline 1-pentene & 0.05 & 0.17 & 0.34 & 1.40 \\
\hline cis-2-pentene & 0.05 & 0.05 & 0.11 & 0.40 \\
\hline trans-2-pentene & 0.11 & 0.11 & 0.25 & 0.80 \\
\hline 1,3-butadiene & 0.08 & 0.05 & 0.07 & 0.50 \\
\hline isoprene & 0.04 & 0.02 & 0.04 & 0.20 \\
\hline Cyclopentene & 0.02 & 0.01 & 0.03 & 0.10 \\
\hline Methylcyclopentene & 0.02 & 0.01 & 0.02 & 0.10 \\
\hline 1-hexene & 0.02 & 0.01 & 0.03 & 0.10 \\
\hline benzene & 0.25 & 0.23 & 0.24 & 2.00 \\
\hline toluene & 1.56 & 1.33 & 1.09 & 11.10 \\
\hline m,p-xylenes & 0.81 & 0.57 & 0.61 & 4.80 \\
\hline o-xylene & 0.27 & 0.19 & 0.19 & 1.70 \\
\hline Ethylbenzene & 0.23 & 0.16 & 0.15 & 1.40 \\
\hline n-propylbenzene & 0.03 & 0.02 & 0.02 & 0.20 \\
\hline Isopropylbenzene & 0.01 & 0.01 & 0.01 & 0.04 \\
\hline m-ethyltoluene & 0.14 & 0.09 & 0.09 & 0.80 \\
\hline p-ethyltoluene & 0.06 & 0.04 & 0.04 & 0.30 \\
\hline o-ethyltoluene & 0.04 & 0.03 & 0.04 & 0.30 \\
\hline styrene & 0.05 & 0.02 & 0.02 & 0.20 \\
\hline 1,3,5-trimethylbenzene & 0.08 & 0.04 & 0.05 & 0.30 \\
\hline 1,2,3-trimethylbenzene & 0.05 & 0.01 & 0.04 & 0.08 \\
\hline 1,2,4-trimethylbenzene\&decane & 0.24 & 0.16 & 0.19 & 1.40 \\
\hline
\end{tabular}




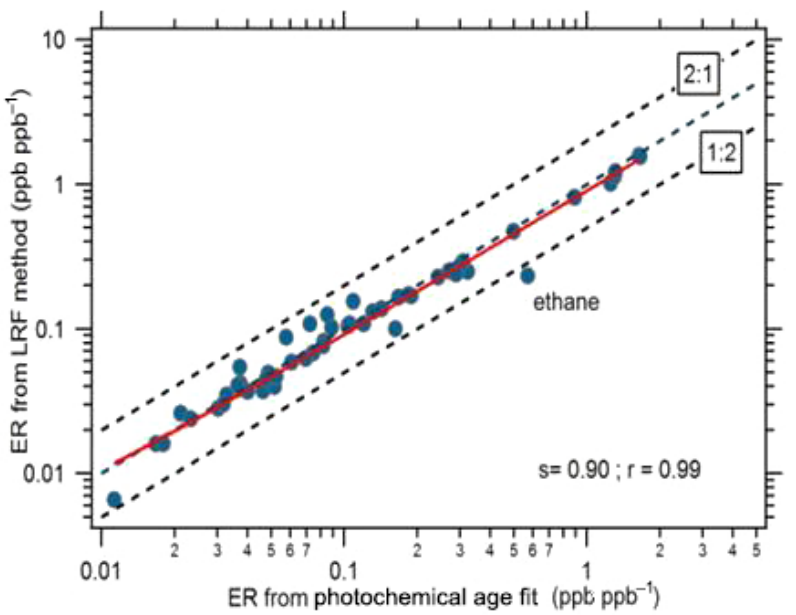

Figure 5. Comparison of the emission ratio (ER) estimated relative to acetylene using the night-time linear regression fit and the photochemical age fit in summer.

\subsection{Performance of the different methods}

Figure 5 illustrates the performance of the ER determination methods for the summer data where ER from the photochemical age and LRF methods are compared. There is an overall very good agreement between the two methods (slope of the linear fit in red $=0.90$ and a correlation coefficient of 0.99), showing the robustness of the methods and confirming that the selection of all the data for less-reactive species and night-time data for more reactive species for summer in the LRF method does not bias the results. The calculated determination coefficients $R^{2}$ with acetylene and $\mathrm{CO}$ ranged from 0.3 for some species like ethane to 0.9 for the majority of the species in winter, while they ranged from 0.5 to 0.9 with acetylene in summer, showing the importance of combustion-related sources during both seasons. The standard deviation of the ER determined by the photochemical method was low and varied between zero and 0.04 for propane. The coefficient of variation was below $3 \%$ for the majority of the species, indicating the robustness of the photochemical method.

\subsection{Emission ratios and seasonal variability}

The ER derived from all winter and summer (night-time dataset for most reactive species) datasets using the LRF method as well as the ER from the road transport established from near-field measurements (Salameh et al., 2014) are summarized in Table 2. ERs relative to $\mathrm{CO}$ were not calculated in summer because $\mathrm{CO}$ data were not available for the whole campaign.

The ER derived from the observations (summer and winter) is comparable to the ratios of the road transport sector at $\pm 50 \%$, during at least one season, for more than $80 \%$ of the species. This shows that urban emission fingerprint is

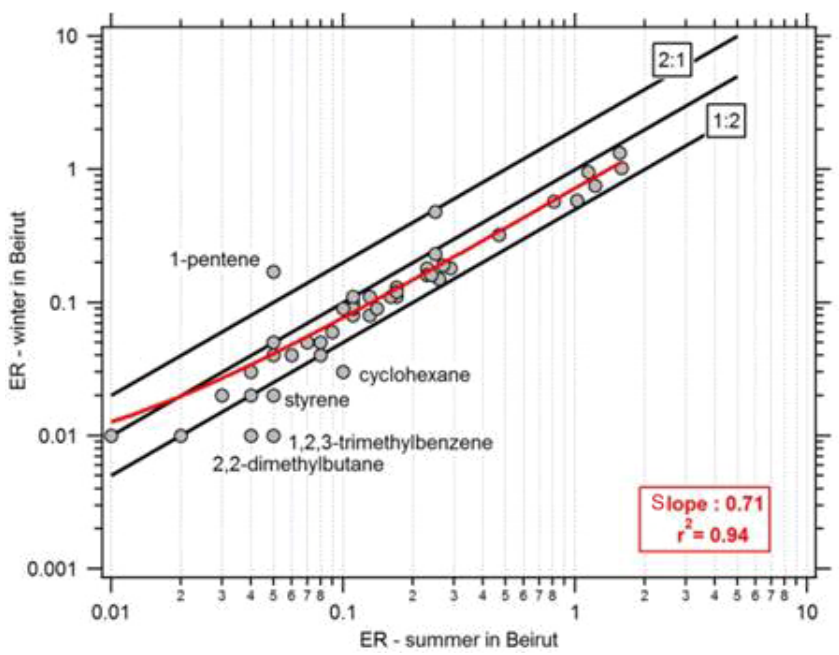

Figure 6. Comparison of summer and winter emission ratios vs. acetylene in Beirut.

mainly driven by traffic emissions, including ethane, which does not have any urban natural gas usage contribution in Lebanon. For other species like, C4 to C6 alkenes, styrene, and a few alkanes, in winter the differences stay within a factor of 2, except for propane where they are within a factor of 5 in summer and 3 in winter. These differences can be partly explained by the contribution of additional sources.

In general, the ERs in winter are slightly lower than in summer (Table 2). Figure 6 compares the emission ratios of NMVOC species relative to acetylene derived at the measurement site during summer and winter. The winter emission ratios for most NMVOC species agree at $\pm 30 \%$ (slope of 0.71) with the summer ERs, within a factor of 2, and with a high determination coefficient of 0.94 . Finally, there is no significant seasonality in ER regardless of the species, except for 1-pentene, cyclohexane, styrene, 2,2-dimethylbutane, and 1,2,3-trimethylbenzene. Those species are associated with ER lower than 0.1. These results indicate that the urban emission composition contributing to the ambient concentrations is not significantly different between summer and winter. The sources usually affected by seasonality are related to combustion in winter and to fuel evaporation in summer. Our results based on ER are consistent with previous PMF results (Salameh et al., 2016), showing that the road transport sector (combustion and gasoline evaporation) is the dominating source in both seasons in Beirut.

These findings are different from the results found in recent studies. For instance, Boynard et al. (2014) found that the emission ratios relative to acetylene in French cities (Paris and Strasbourg) are slightly affected by the seasonality of emissions for benzene and alkenes, whereas other NMVOC species (alkanes and higher aromatics) exhibit emission ratios in summer that are a factor of 3 to 7 higher. Moreover, Wang et al. (2014) reported lower winter emis- 

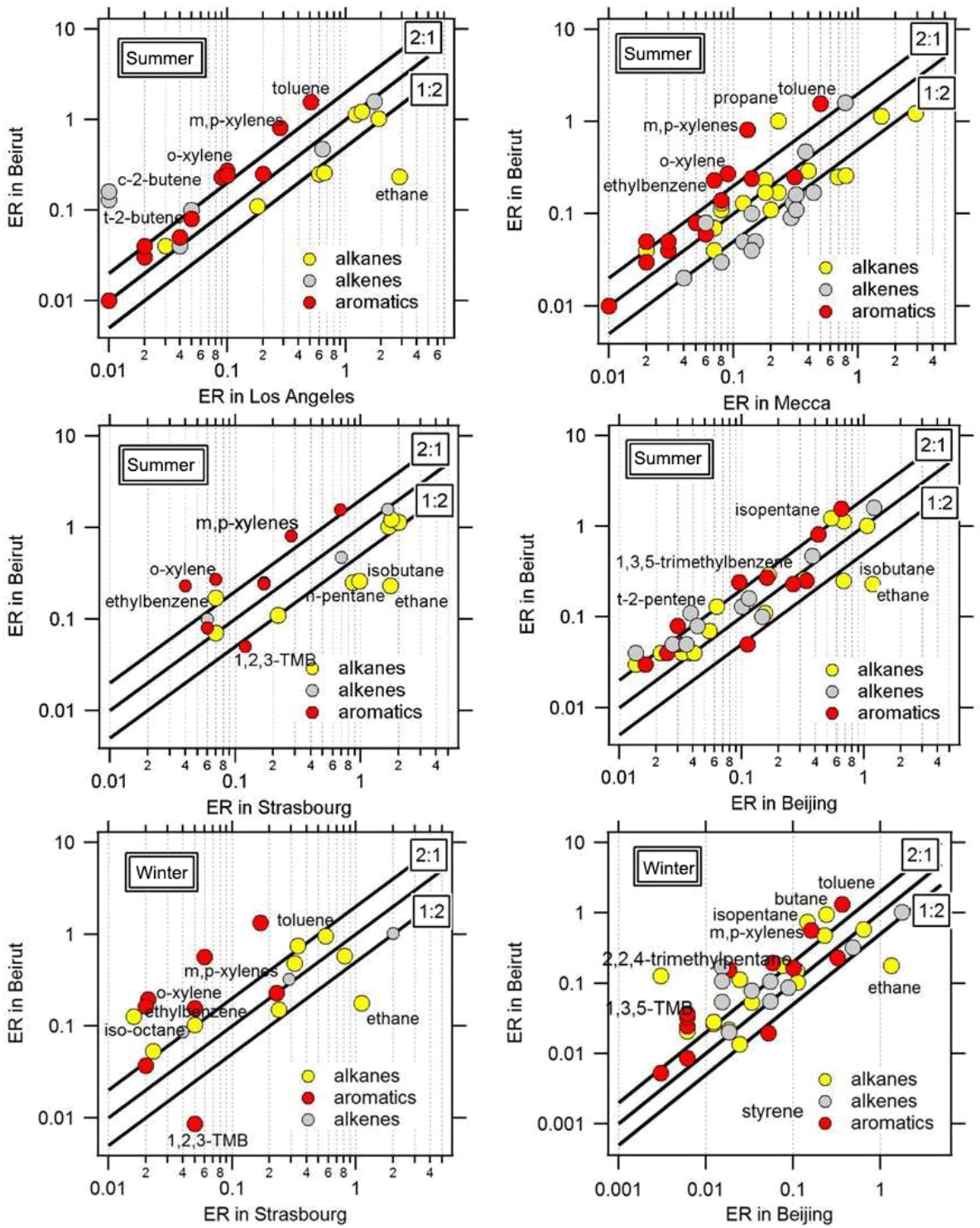

Figure 7. Comparisons of NMVOC emission ratios determined at the Beirut suburban site with those for Los Angeles, US (Borbon et al., 2013); Strasbourg, France (Boynard et al., 2014); Beijing, China (Wang et al., 2014); and Mecca, Saudi Arabia (Simpson et al., 2014) (TMB: Trimethylbenzene).

sion ratios for most NMVOC species than the summer values by a factor $\geq 2$ in Beijing, China. This seasonal difference in emission ratios for most NMVOC species is possibly due to the seasonal variations in NMVOC sources and in particular the modulation between winter combustion and summer evaporation.

\section{Comparison to other cities worldwide}

The NMVOC emission ratios relative to acetylene determined in Beirut by the LRF method are compared to those recently determined in contrasted cities of North America (Los Angeles, USA), Europe (Strasbourg, France), the Mid- dle East (Mecca, Saudi Arabia), and Asia (Beijing, China) on a seasonal basis in Fig. 7.

Usually ERs agree within a factor of 2, except for aromatics (except benzene) and some alkanes (C2-C5). Those species are related to the unburned fuel fraction and natural gas or liquefied petrol usage.

Among C2-C5 alkanes and regardless of the season, ER of ethane is much lower in Beirut than Los Angeles, Beijing, and Strasbourg, but it is similar to Saudi Arabia since the natural gas source is not widely used in Lebanon and Middle Eastern countries (Salameh et al., 2015). Regardless of the season, ERs of aromatics are higher in Beirut compared to northern post-industrialized countries and even the Middle 
Table 3. List of target species and their $k_{\mathrm{OH}}$ (Atkinson and Arey, 2003; Atkinson, 2007) and $y_{\mathrm{SOA}}$ (SOA formation potential) (Derwent et al., 2010).

\begin{tabular}{|c|c|c|c|}
\hline $\begin{array}{l}\text { ACCMIP nomenclature } \\
\text { MACCity* }\end{array}$ & $\begin{array}{l}\text { Compounds considered from } \\
\text { ECOCEM database }\end{array}$ & $\begin{array}{l}k_{\mathrm{OH}}\left(10^{-12} \mathrm{~cm}^{3}\right. \\
\left.\text { molecule }{ }^{-1} \mathrm{~s}^{-1}\right)\end{array}$ & $y_{\mathrm{SOA}}$ \\
\hline Ethane* & Ethane & 0.25 & 0.1 \\
\hline Propane* & Propane & 1.09 & 0 \\
\hline Butanes & Butane and isobutane & 2.36 and 2.12 & 0.3 and 0 \\
\hline Pentanes & Pentane and isopentane & 3.8 and 3.6 & 0.3 and 0.2 \\
\hline Ethene* & Ethene & 8.52 & 1.3 \\
\hline Propene* & Propene & 26.3 & 1.6 \\
\hline Acetylene & Acetylene & 0.9 & 0.1 \\
\hline Benzene & Benzene & 1.22 & 92.9 \\
\hline Trimethylbenzene & Sum of 1,2,3-1,2,4-,1,3,5-trimethylbenzene & $32.7 ; 32.5 ; 56.7$ & $43.9 ; 20.6 ; 13.5$ \\
\hline Toluene & Toluene & 5.63 & 100 \\
\hline Xylenes & Sum of m,p-xylenes and o-xylene & $13.6 ; 23.1 ; 14.3$ & $95.5 ; 84.5 ; 67.1$ \\
\hline $\mathrm{CO}^{*}$ & $\mathrm{CO}$ & & \\
\hline
\end{tabular}

* Compounds present in both ACCMIP and MACCity emission inventories. (Absence of * means that the compounds are only present in the ACCMIP emission inventory.)

Eastern city of Mecca. One should note that aromatic differences are quite significant between the two Middle Eastern cities, from a factor of 3 up to a factor of 6 for $(\mathrm{m}, \mathrm{p})$-xylenes. The maximum difference is observed between Beirut and Strasbourg, and it reached a factor of 10 for $\mathrm{m}, \mathrm{p}$-xylenes in winter. Differences are greater in winter than in summer as a consequence of a marked seasonal variability of ER in other cities (Strasbourg and Beijing) in contrast to Beirut. In Beirut, the aromatics are emitted from combustion-related sources and from gasoline evaporation, which accounts for more than $40 \%$ in winter as well as in summer (Salameh et al., 2016). ERs of alkenes, which are combustion products, usually agree within a factor of 2 between Beirut, Los Angeles, Beijing, and Strasbourg in both seasons, except for C4 and $\mathrm{C} 5$ alkenes for LA and Beijing. Whereas, alkene ERs are higher in Mecca due to their additional evaporative origin (Simpson et al., 2014).

\section{Evaluation of global emission inventories for anthropogenic speciated VOC emissions}

The emission fluxes $\left(\mathrm{kg} \mathrm{m}^{-2} \mathrm{~s}^{-1}\right)$ extracted from the ECCAD database are converted to mole emission fluxes, and then the NMVOC ratios relative to $\mathrm{CO}$ and relative to acetylene are determined.

When possible, the comparison held here will consider the common compounds present in the ACCMIP and MACCity global emission inventories and measured during ECOCEM campaigns, which are listed in Table 3. Important NMVOC species are present within these inventories as tracers of many anthropogenic sources, reactive species, and important precursors of ozone and SOA (Table 3). We consider the speciation as "reasonable" when there is an agreement within a factor of 2 between observations and emission inventory.

\subsection{Emission inventory vs. observations: all anthropogenic sectors}

To analyse the consistency of the speciation of NMVOCs in the ACCMIP and MACCity global emission inventories, we compared the individual NMVOC relative to $\mathrm{CO}$ as well as acetylene ratios during summer and winter obtained by the LRF method. Figure 8 displays the ratios from the anthropogenic emissions data (ACCMIP and MACCity) and the observations in a logarithmic scale for 11 individual NMVOC species, colour coded by the NMVOC groups. Except benzene, xylenes, and long-lived alkanes, ER relative to acetylene agree within a factor of 2 between observations and inventory, suggesting that the VOC speciation in ACCMIP is better represented for more reactive VOCs such as alkenes and some aromatics. Regarding ER relative to $\mathrm{CO}$, differences with ACCMIP are significant. A global underestimation by the inventory of a shift towards lower ER over an order of magnitude is observed, suggesting an overestimation of $\mathrm{CO}$ emissions by ACCMIP.

In order to consolidate our conclusions regarding VOC speciation within ACCMIP, we performed the systematic calculation of the ratios of every NMVOC to each of the other NMVOCs $\left(\mathrm{NMVOC}_{i}\right)$ in the global emission inventory and in the observations (Coll et al., 2010) separately. Then we reported the ERs obtained from ACCMIP vs. those obtained from the observations in Fig. 9. From Fig. 9, it appears that benzene is systematically overestimated up to a factor of 5 in ACCMIP and to a lesser extent, pentanes and butanes are overestimated by a factor $>2$. Conversely, xylenes are underestimated in the ACCMIP global emission inventory but not systematically. The other compounds are closer to the line of the slope $(=1)$, below a factor of 2 . Finally, comparisons between ACCMIP and observations (Figs. 8 and 9) suggest 

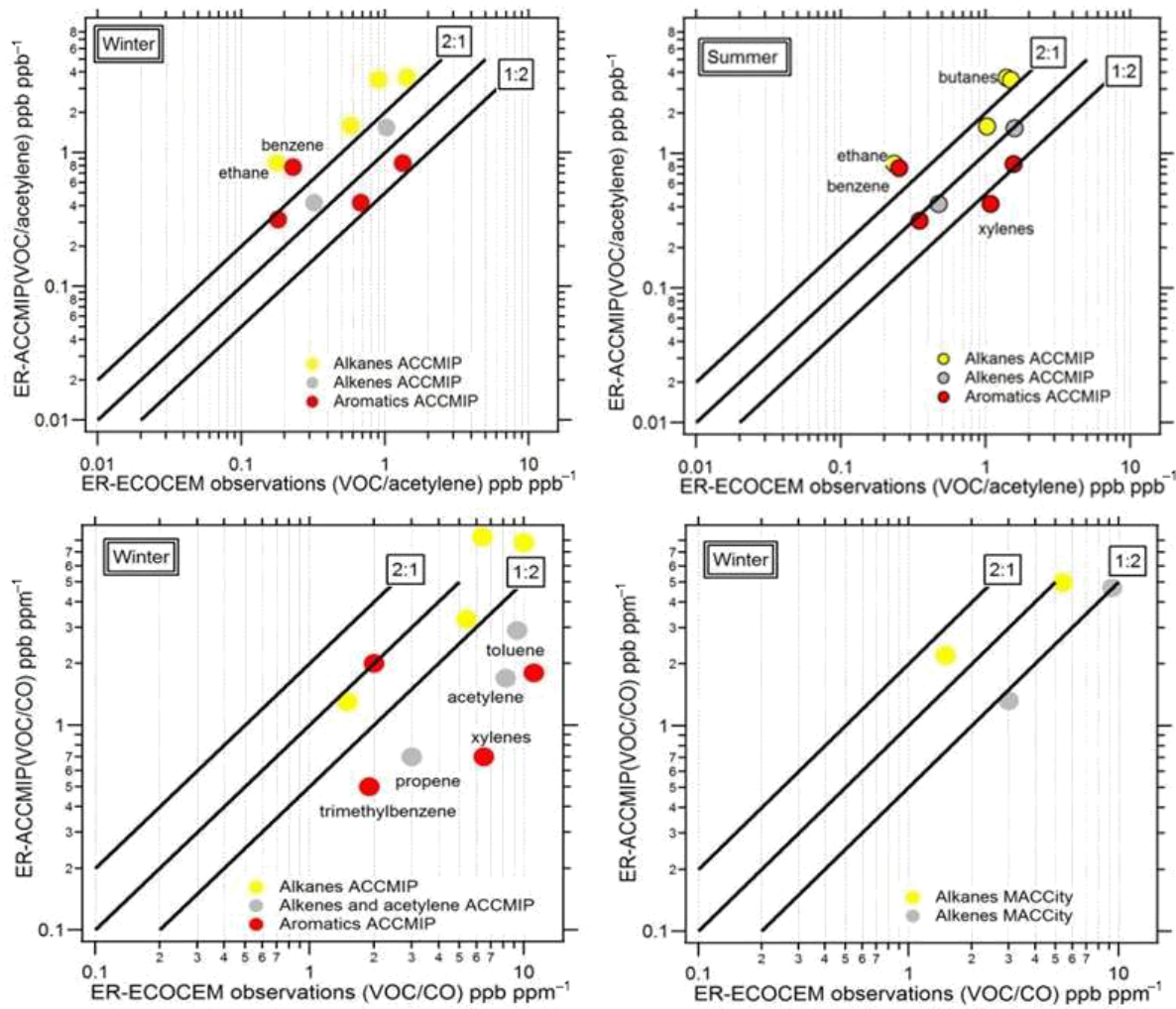

Figure 8. Comparison of the emission ratios from ACCMIP and MACCity to the ones measured by LRF method in summer and in winter relative to $\mathrm{CO}$ and acetylene for all the anthropogenic sectors.

that the overall speciation of anthropogenic sources for major hydrocarbons that act as ozone and SOA precursors in ACCMIP is better represented than the others species, but it still needs improvement.

\subsection{Emission inventory vs. observations: road transport sector}

Our study shows that calculated ERs are comparable to those from the road transport sector for more than $80 \%$ of the species (Table 2), which is consistent with PMF results (Salameh et al., 2016). In Lebanon, PMF results showed that the major sources of NMHCs were traffic-related emissions (combustion and gasoline evaporation) in winter and in summer accounting for 51 and $74 \mathrm{wt} \%$ respectively. Moreover, according to Parrish et al. (2009), the largest source of emissions in most urban areas is road traffic, which includes tailpipe and evaporative emissions. Therefore, it is also crucial to assess the emission inventories regarding the road transport sector, namely ACCMIP and EMEP SNAP 07.

We proceeded as in the previous section by comparing the road transport ER relative to acetylene for all VOCs and individual VOCs from ACCMIP and EMEP emission inventories to the ER from near-field measurements (Figs. 10 and 11) (Salameh et al., 2014). ERs of alkenes from the road transport sector are usually consistent within a factor of 2 for the regional emission inventory EMEP and the global inventory ACCMIP. In EMEP, benzene and ethane are overestimated whereas butanes are underestimated, while xylenes and toluene are underestimated over a factor of 2 by ACCMIP. At a more detailed level, by calculating the ratios for individual NMVOCs, Fig. 11 confirms that xylenes and toluene are underestimated species by both inventories, and benzene is overestimated by EMEP.

\subsection{Perspectives for Middle Eastern region (MEA)}

After a focus on Lebanon, the purpose of this last section is to provide some perspective regarding the whole MEA region. Figure 12 shows the comparison of ER relative to acetylene from the ACCMIP emission inventory considering all the anthropogenic sectors of Lebanon compared to the ones of four other Middle Eastern countries that are expected to be high VOC emitters (Saudi Arabia, Egypt, Iran, and Turkey). An overall agreement within a factor of 2 of the ERs is observed between countries on the Mediterranean border (Lebanon, Turkey, and Egypt). However, when comparing Lebanon to other Middle Eastern countries, some gaps are depicted: the emission inventory suggests that the ERs of benzene, toluene, and C4-C5 alkanes are lower in Lebanon compared to Iran and Saudi Arabia. For the latter, those observations are completely contradictory with the ones reported in Fig. 7. 

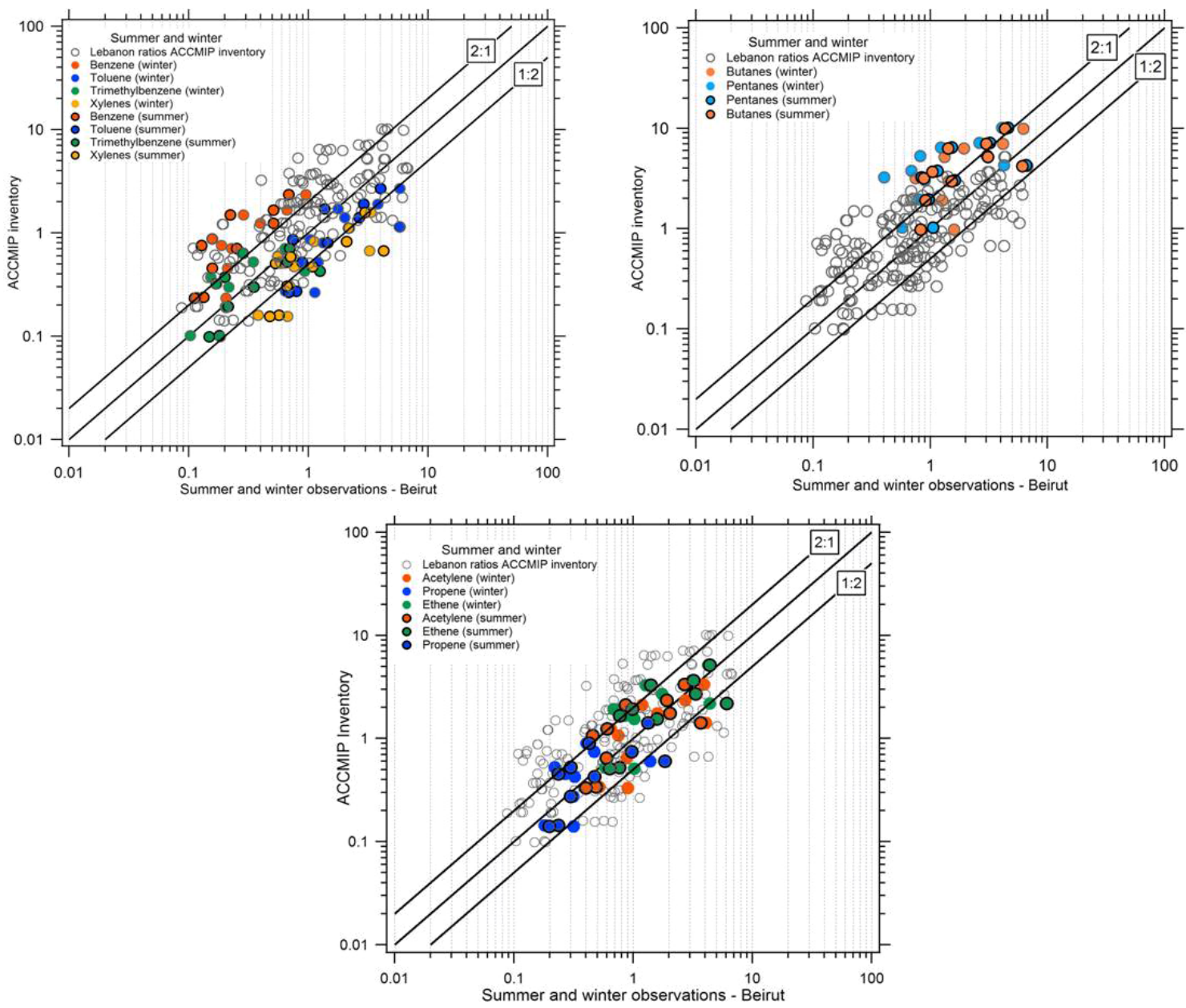

Figure 9. Comparison of the emission ratios of NMVOC vs. NMVOC $i$ from ACCMIP to the measured ones, in summer and in winter, for all the anthropogenic sectors, for all data of all compound classes (in grey dots), and for a given NMVOC (coloured dots).

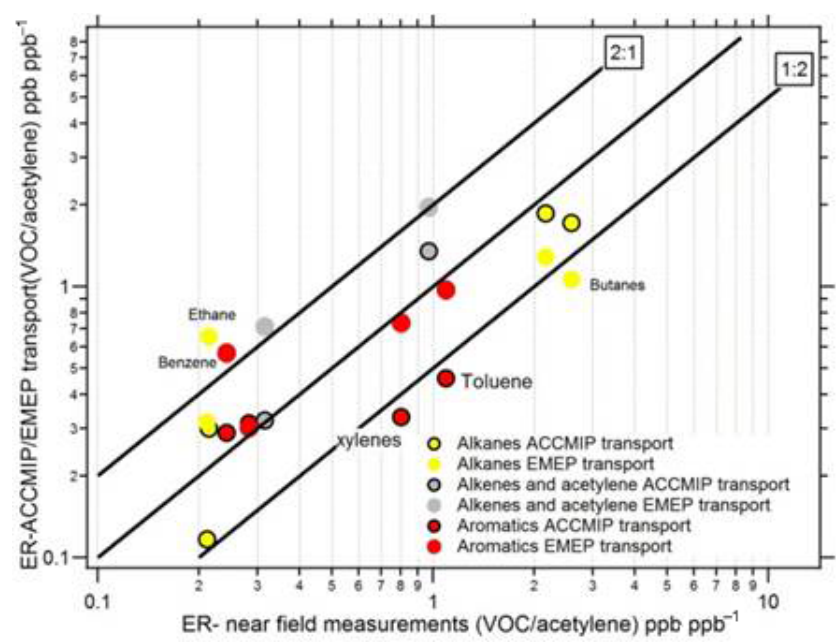

Figure 10. Comparison of the emission ratios relative to acetylene from the ACCMIP and EMEP emission inventories for road transport and the ER from road transport using near-field measurements.
We show that the anthropogenic emissions in Beirut were more enriched in aromatics and propane and poorer in some alkenes than the ones of Mecca, while benzene ER was consistent between both countries. While the comparison here is limited by the number of species compared to Fig. 7, this suggests that the global emission inventory does not reproduce the heterogeneity of VOC anthropogenic emission composition between countries of the MEA. This could be indicative for other MEA countries where emissions data and measurements are scarce. Systematic and additional observations are needed in order to test the importance of such spatial variability in anthropogenic VOC emission composition.

\section{Conclusions}

Detailed measurements of NMVOCs collected at a suburban site in Beirut, Lebanon, were used to evaluate regional and global emission inventories (ACCMIP, MACCity, and EMEP) downscaled to the studied domain. These data were 

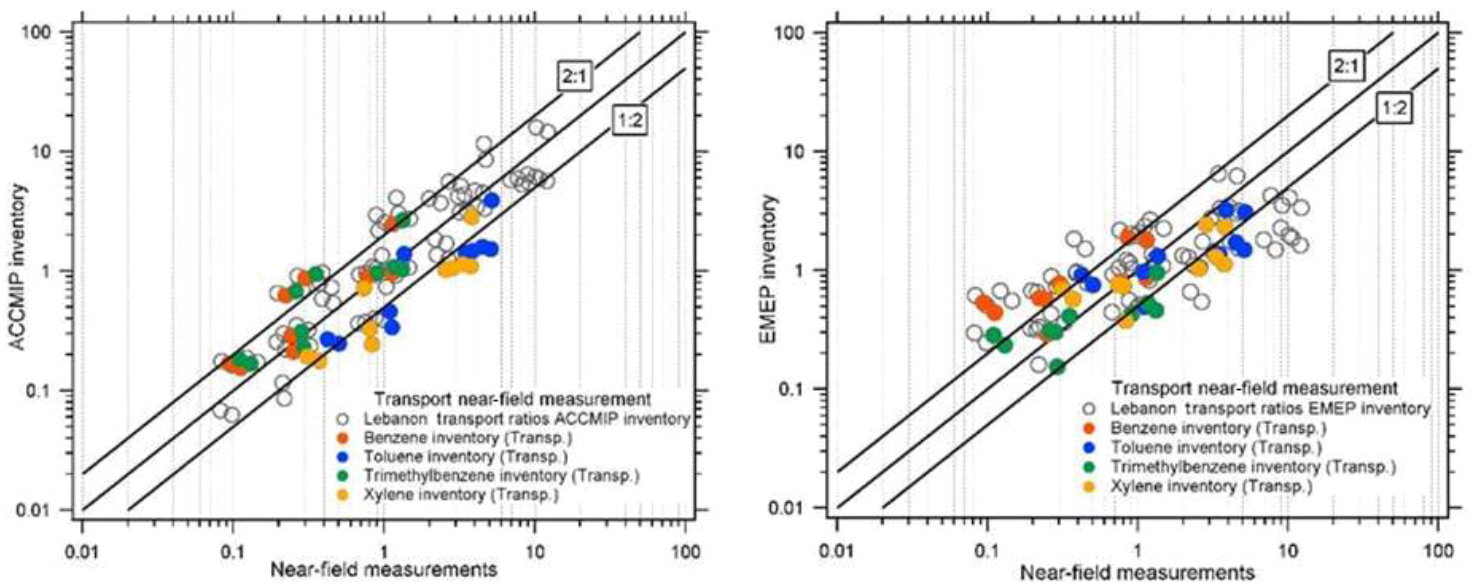

Figure 11. Comparison of the emission ratios of NMVOC vs. NMVOCi from ACCMIP and EMEP with the ER from near-field measurements for the road transport sector, for all data (in grey dots) and for a given NMVOC (coloured dots).
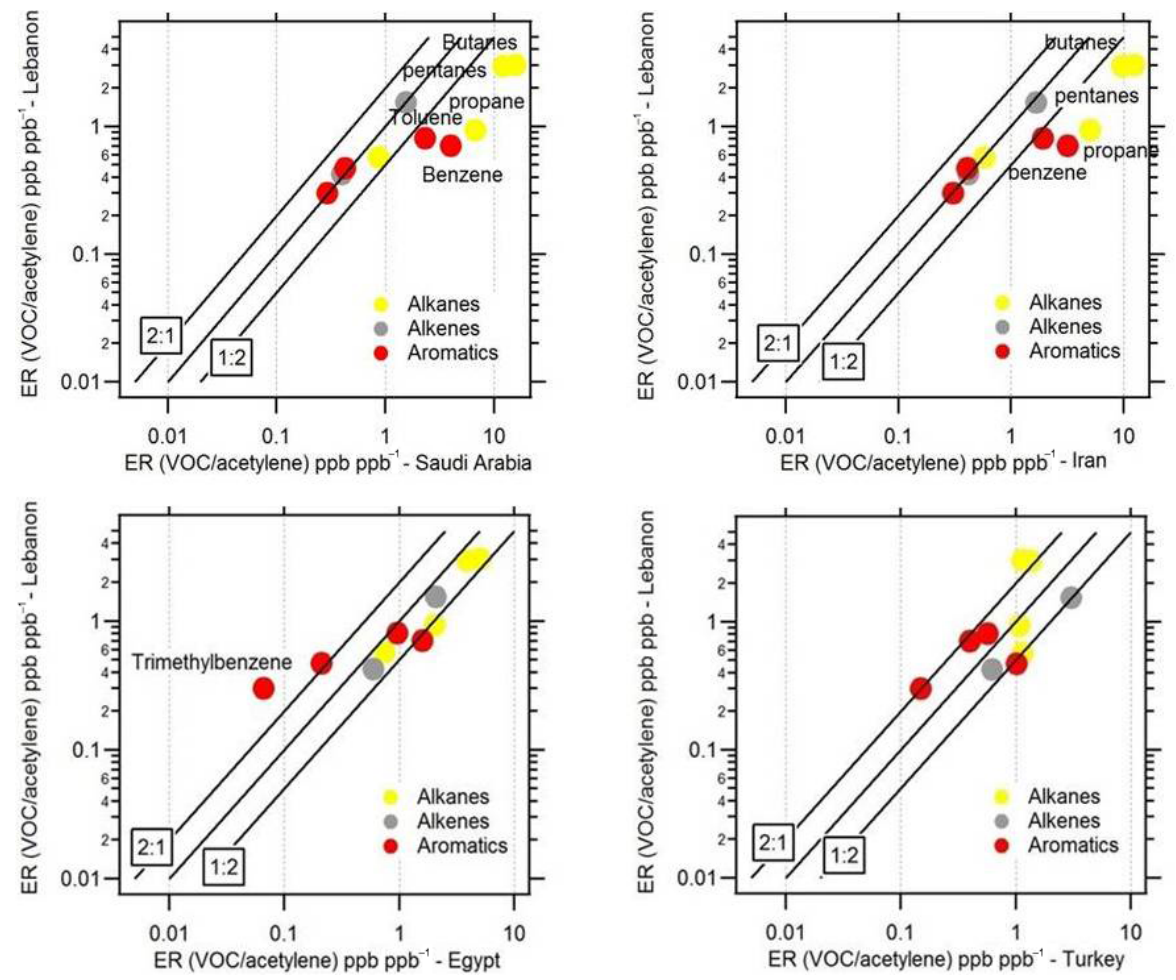

Figure 12. Comparison of the emission ratios from ACCMIP relative to acetylene for all the anthropogenic sectors for five Middle Eastern countries (Lebanon, Egypt, Turkey, Iran, and Saudi Arabia).

collected during two intensive field campaigns in summer 2011 and in winter 2012 within the framework of the ECOCEM project.

The emission ratios (ERs) of individual NMVOC species relative to $\mathrm{CO}$ and acetylene were successfully derived from ambient measurements in summer and in winter as well as from near-field measurements for the road transport sector by applying two independent methods: the linear regression fit method and the photochemical age method. Emission ratios from both methods show a very good agreement at $\pm 10 \%$.

The ERs derived from the observations (summer and winter) are comparable to the ratios of the road transport sector for more than $80 \%$ of the species. There is generally no significant seasonality in ER regardless of the species, unlike the seasonality usually observed in other cities. These results are consistent with the significant contribution of the road trans- 
port sector (combustion and gasoline evaporation) in winter and summer (Salameh et al., 2016).

Regardless of the season, ERs derived from observations agree within a factor of 2 between Beirut and other representative worldwide cities, except for the unburned fuel fraction and ethane. Aromatics (except benzene) show the largest differences up to a factor of 10 for $\mathrm{m}, \mathrm{p}$-xylenes compared to northern post-industrialized countries and even another Middle Eastern city like Mecca in Saudi Arabia.

ER relative to $\mathrm{CO}$ and to acetylene as well as the ratios of every NMVOC to each of the other NMVOCs $\left(\mathrm{NMVOC}_{i}\right)$ extracted from ACCMIP and MACCity global emission inventories were compared with the corresponding observed ER during both seasons for all anthropogenic sectors. This comparison suggests that the overall speciation of anthropogenic sources for major hydrocarbons that act as ozone and SOA precursors in ACCMIP is better represented than other species but it still needs improvement.

The road transport ERs relative to acetylene derived from near-field measurements are compared to ERs from ACCMIP and EMEP regional emission inventory for the road transport sector. ERs of more reactive species (alkenes and aromatics except benzene) are usually consistent within a factor of 2 for the regional emission inventory EMEP, while xylenes and toluene are underestimated by over a factor of 2 by ACCMIP.

It should be emphasized that when a consensus is met between observed and inventory ERs (the ERs fall around the ratio of 1), this does not necessarily mean that the absolute emissions are correct. Indeed, Salameh et al. (2016) showed that global inventories (ACCMIP, EDGAR, MACCity) could underestimate the NMVOC emissions by up to a factor of 10 for the transportation sector. Both speciation and absolute emissions have to be taken into consideration.

Finally, we have shown that the emission inventory is in disagreement with the observations when comparing Lebanon to Saudi Arabia. The observed heterogeneity of anthropogenic VOC emission composition can be significant for reactive VOC (factor of 6 for m,p-xylenes), but it is not depicted by global emission inventories. This suggests that systematic and detailed measurements are needed in the MEA region in order to better constrain emission inventories. VOC emission inventory is the fundamental input of air quality modelling, therefore it plays a major role in characterizing secondary pollution and control policy formulation. To improve the quality of future VOC emission estimates, more efforts should be made toward refinement of source classification, development of representative local emission factors, comprehensive collection of activity data, and more accurate spatio-temporal characterization. Additionally, comparison of available datasets will allow a quantification of the uncertainties on emissions.

At a regional and global level, long term and continuous studies integrating more than one measuring site and more specific tracers are of great interest in order to provide more reliable information, and the use of surface observations from monitoring stations could help define better speciations.

\section{Data availability}

Three papers cited in this paper for Salameh et al. (2014, $2015,2016)$ provide the data sets used in this paper. The data will be available at the ChArMEx website http://charmex. lsce.ipsl.fr/index.php/charmex-database.html.

Acknowledgements. Funding for this study was obtained from Mines Douai Institution, the Lebanese National Council for Scientific Research, Saint Joseph University (Faculty of Sciences and the Research Council), CEDRE (Coopération pour l'Évaluation et le Développement de la Recherche), and PICS no. 5630 (Programme Interorganismes de Coopération Scientifique du CNRS). This work is also part of the ChArMEx program. ChArMEx is the atmospheric component of the French multidisciplinary program MISTRALS (Mediterranean Integrated Studies aT Regional And Local Scales). ChArMEx-France was principally funded by INSU, ADEME, ANR, CNES, CTC (Corsica region), EU/FEDER, Météo-France, and CEA. Thérèse Salameh's postdoc is supported by DIM R2DS from Région Ile-de-France (2014-09).

Edited by: N. Mihalopoulos

Reviewed by: two anonymous referees

\section{References}

Atkinson, R.: Gas-phase tropospheric chemistry of organic compounds: a review, Atmos. Environ., 41, 200-240, doi:10.1016/J.ATMOSENV.2007.10.068, 2007.

Atkinson, R. and Arey, J.: Atmospheric degradation of volatile organic compounds, Chem. Rev. 103, 4605, doi:10.1021/CR0206420, 2003.

Badol, C., Locoge, N., Léonardis, T., and Gallo, J.-C.: using a source-receptor approach to characterise VOC behaviour in a French urban area influenced by industrial emissions, Part I: Study area description, data set acquisition and qualitative data analysis of the data set, Sci. Total Environ., 389, 441-452, 2008.

Borbon, A., Fontaine, H., Veillerot, M., Locoge, N., Galloo, J. C., and Guillermo, R.: An investigation into the traffic related fraction ofisoprene at an urban location, Atmos. Environ., 35, 37493760, 2001.

Borbon, A., Gilman, J. B., Kuster, W. C., Grand, N., Chevaillier, S., Colomb, A., Dolgorouky, C., Gros, V., Lopez, M., SardaEsteve, R., Holloway, J., Stutz, J., Perrussel, O., Petetin, H., McKeen, S., Beekmann, M., Warneke, C., Parrish D. D., and de Gouw, J. A.: Emission ratios of anthropogenic VOC in northern mid-latitude megacities: observations vs. emission inventories in Los Angeles and Paris, J. Geophys. Res., 118, 2041-2057, doi:10.1002/jgrd.50059, 2013.

Boynard, A., Borbon, A., Leonardis, T., Barletta, B., Meinardi, S., Blake, D. R., and Locoge, N.: Spatial and seasonal variability of measured anthropogenic non-methane hydrocarbons in urban 
atmospheres: Implication on emission ratios, Atmos. Environ., 82, 258-267, doi:10.1016/j.atmosenv.2013.09.039, 2014.

Coll, I., Rousseau, C., Barletta, B., Meinardi, S., and Blake, D. R.: Evaluation of an urban NMHC emission inventory by measurements and impact on CTM results, Atmos. Environ., 44, 38433855, 2010.

de Gouw, J. A., Middlebrook, A. M., Warneke, C., Goldan, P. D., Kuster, W. C., Roberts, J. M., Fehsenfeld, F. C., Worsnop, D. R., Canagaratna, M. R., Pszenny, A. A. P., Keene, W. C., Marchewka, M., Bertman, S. B., and Bates, T. S.: Budget of organiccarbon in a polluted atmosphere: Results from the New England Air Quality Study in 2002, J. Geophys. Res.-Atmos., 110, D16305, doi:10.1029/2004jd005623, 2005.

Derwent, R. G., Jenkin, M. E., Utembe, S. R., Shallcross, D. E., Murrells, T. P., and Passant, N. R.: Secondary organic aerosol formation from a large number of reactive man-made organic compounds, Sci. Total Environ., 408, 3374-3381, 2010.

ECCAD: ECCAD database, available at: http://eccad.sedoo.fr/ eccad_extract_interface/JSF/page_products_em.jsf, last access: November 2015.

EMEP/EEA: Air Pollutant Emission Inventory Guidebook, available at: www.eea.europa.eu (last access: November 2015), 2009.

Granier, C., Bessagnet, B., Bond, T., D’Angiola, A., van der Gon, H. D., Frost, G. J., Heil, A., Kaiser, J. W., Kinne, S., Klimont, Z., Kloster, S., Lamarque, J.-F., Liousse, C., Masui, T.,Meleux, F., Mieville, A., Ohara, T., Raut, J.-C., Riahi, K., Schultz, M. G., Smith, S. J., Thompson, A., van Aardenne, J., van der Werf, G. R., and van Vuuren, D. P.: Evolution of anthropogenic and biomass burning emissions of air pollutants at global and regional scales during the 1980-2010 period, Climatic Change, 109, 163-190, doi:10.1007/s10584-011-0154-1, 2011.

Gurjar, B., Butler, T., Lawrence, M., and Lelieveld, J.: Evaluation of emissions and air quality in megacities, Atmos. Environ., 42, 1593-1606, 2008.

Hilboll, A., Richter, A., and Burrows, J. P.: Long-term changes of tropospheric $\mathrm{NO}_{2}$ over megacities derived from multiple satellite instruments, Atmos. Chem. Phys., 13, 4145-4169, doi:10.5194/acp-13-4145-2013, 2013.

Im, U., Poupkou, A., Incecik, S., Markakis, K., Kindap, T., Unal, A., Melas, D., Yenigun, O., Topcu, S., Odman, M. T., Tayanc, M., and Guler, M.: The impact of anthropogenic and biogenic emissions on surface ozone concentrations in Istanbul, Sci. Total Environ. 409, 1255-1265, 2011.

Kanakidou, M., Mihalopoulos, N., Kindap, T., Im, U., Vrekoussis, M., Gerasopoulos, E., Dermitzaki, E., Unal, A., Koçak, M., Markakis, K., Melas, D., Kouvarakis, G., Youssef, A. F., Richter, A., Hatzianastassiou, N., Hilboll, A., Ebojie, F., Wittrock, F., von Savigny, C., Burrows, J. P., Ladstaetter-Weissenmayer, A., and Moubasher, H.: Megacities as hot spots of air pollution in the East Mediterranean, Atmos. Environ., 45, 1223-1235, doi:10.1016/j.atmosenv.2010.11.048, 2011.

Kim, S.-W., McKeen, S. A., Frost, G. J., Lee, S.-H., Trainer, M., Richter, A., Angevine, W. M., Atlas, E., Bianco, L., Boersma, K. F., Brioude, J., Burrows, J. P., de Gouw, J., Fried, A., Gleason, J., Hilboll, A., Mellqvist, J., Peischl, J., Richter, D., Rivera, C., Ryerson, T., te Lintel Hekkert, S., Walega, J., Warneke, C., Weibring, P., and Williams, E.: Evaluations of $\mathrm{NO}_{x}$ and highly reactive VOC emission inventories in Texas and their implications for ozone plume simulations during the Texas Air Quality Study
2006, Atmos. Chem. Phys., 11, 11361-11386, doi:10.5194/acp11-11361-2011, 2011.

Konovalov, I. B., Beekmann, M., Richter, A., Burrows, J. P., and Hilboll, A.: Multi-annual changes of $\mathrm{NO}_{x}$ emissions in megacity regions: nonlinear trend analysis of satellite measurement based estimates, Atmos. Chem. Phys., 10, 8481-8498, doi:10.5194/acp-10-8481-2010, 2010.

Lamarque, J.-F., Bond, T. C., Eyring, V., Granier, C., Heil, A., Klimont, Z., Lee, D., Liousse, C., Mieville, A., Owen, B., Schultz, M. G., Shindell, D., Smith, S. J., Stehfest, E., Van Aardenne, J., Cooper, O. R., Kainuma, M., Mahowald, N., McConnell, J. R., Naik, V., Riahi, K., and van Vuuren, D. P.: Historical (1850-2000) gridded anthropogenic and biomass burning emissions of reactive gases and aerosols: methodology and application, Atmos. Chem. Phys., 10, 7017-7039, doi:10.5194/acp10-7017-2010, 2010.

Lelieveld, J., Hoor, P., Jöckel, P., Pozzer, A., Hadjinicolaou, P., Cammas, J.-P., and Beirle, S.: Severe ozone air pollution in the Persian Gulf region, Atmos. Chem. Phys., 9, 1393-1406, doi:10.5194/acp-9-1393-2009, 2009.

Lelieveld, J., Hadjinicolaou, P., Kostopoulou, E., Chenoweth, J., Giannakopoulos, C., Hannides, C., Lange, M. A., El Maayar, M.,Tanarhte, M., Tyrlis, E., and Xoplaki, E.: Climate change and impacts in the Eastern Mediterranean and the Middle East, Climatic Change, 114, 667-687, 2012.

Lelieveld, J., Beirle, S., Hörmann, C., Stenchikov, G., and Wagner, T.: Abrupt recent trend changes in atmospheric nitrogen dioxide over the Middle East, Sci. Adv., 1, e1500498, doi:10.1126/sciadv.1500498, 2015.

Markakis, K., Im, U., Unal, A., Melas, D., Yenigun, O., and Incecik, S.: Compilation of a GIS based high spatially and temporally resolved emission inventory for the greater Istanbul area, Atmos. Pollut. Res., 3, 112-125, 2012.

Martin, R. V., Jacob, D. J., Chance, K., Kurosu, T. P., Palmer, P. I., and Evans, M. J.: Global inventory of nitrogen oxides emissions constrained by space-based observations of $\mathrm{NO}_{2}$ columns, J. Geophys. Res., 108, 4537, doi:10.1029/2003JD003453, 2003.

Parrish, D. D., Kuster, W. C., Shao, M., Yokouchi, Y., Kondo, Y., Goldan, P. D., de Gouw, J. A., Koike, M., and Shirai, T.: Comparison of air pollutant emissions among mega-cities, Atmos. Environ., 43, 6435-6441, doi:10.1016/j.atmosenv.2009.06.024, 2009.

Pozzer, A., Zimmermann, P., Doering, U. M., van Aardenne, J., Tost, H., Dentener, F., Janssens-Maenhout, G., and Lelieveld, J.: Effects of business-as-usual anthropogenic emissions on air quality, Atmos. Chem. Phys., 12, 6915-6937, doi:10.5194/acp12-6915-2012, 2012.

Salameh, T., Afif, C., Sauvage, S., Borbon, A., and Locoge, N.: Speciation of Non- Methane Hydrocarbons (NMHC) from anthropogenic sources in Beirut, Lebanon, Environ. Sci. Pollut. R., 21, 10867-10877, doi:10.1007/s11356-014-2978-5, 2014.

Salameh, T., Sauvage, S., Afif, C., Borbon, A., Leonardis, T., Brioude, J., Waked, A., and Locoge, N.: Exploring the seasonal NMHC distribution in an urban area of the Middle East during ECOCEM campaigns: very high loadings dominated by local emissions and dynamics, Environ. Chem, 12, 316-328, doi:10.1071/EN14154, 2015.

Salameh, T., Sauvage, S., Afif, C., Borbon, A., and Locoge, N.: Source apportionment vs. emission inventories of non-methane hydrocarbons (NMHC) in an urban area of the Middle East: local 
and global perspectives, Atmos. Chem. Phys., 16, 3595-3607, doi:10.5194/acp-16-3595-2016, 2016.

Sauvage, S., Plaisance, H., Locoge, N., Wroblewski, A., Coddeville, P., and Galloo, J. C.: Long term measurement and source apportionment of non-methane hydrocarbons in three French rural areas, Atmos. Environ., 43, 2430-2441, 2009.

Schultz, M., Rast, S., van het Bolscher, M., Pulles, T., Pereira, J., Spessa, A., Dalsøren, S., van Nojie, T., and Szopa, S.: REanalysis of the TROpospheric chemical composition over the past 40 years, A long-term global modeling study of tropospheric chemistry funded under the 5th EU framework programme, Tech. rep., EU-Contract No. EVK2-CT-2002-00170, Max Planck Institute for Meteorology, Germany, 2007.

Simpson, I. J., Aburizaiza, O. S., Siddique, A., Barletta, B., Blake, N. J., Gartner, A., Khwaja, H., Meinardi, S., Zeb, J., and Blake, D. R.: Air Quality in Mecca and Surrounding Holy Places in Saudi ArabiaDuring Hajj: Initial Survey, Environ. Sci. Technol., 48, 8529-8537, doi:10.1021/es5017476, 2014.

Uherek, E., Halenka, T., Borken-Kleefeld, J., Balkanski, Y., Berntsen, T., Borrego, C., Gauss, M., Hoor, P., Juda-Rezler, K., Lelieveld, J., Melas, D., Rypdal, K., and Schmid, S.: Transport impacts on atmosphere and climate: Land transport, Atmos. Environ. 44, 4772-4816, 2010.

Von Schneidemesser, E., Monks, P. S., and Plass-Duelmer, C.: Global comparison of VOC and $\mathrm{CO}$ observations in urban areas, Atmos. Environ., 44, 5053-5064, doi:10.1016/j.atmosenv.2010.09.010, 2010.

Waked, A. and Afif, C.: Emissions of air pollutants from road transport in Lebanon and other countries in the Middle East region, Atmos. Environ., 61, 446-452, 2012.
Waked, A., Afif, C., and Seigneur, C.: An atmospheric emission inventory of anthropogenic and biogenic sources for Lebanon, Atmos. Environ., 50, 88-96, 2012.

Waked, A., Seigneur, C., Couvidat, F., Kim, Y., Sartelet, K., Afif, C., Borbon, A., Formenti, P., and Sauvage, S.: Modeling air pollution in Lebanon: evaluation at a suburban site in Beirut during summer, Atmos. Chem. Phys., 13, 5873-5886, doi:10.5194/acp13-5873-2013, 2013.

Wang, M., Shao, M., Chen, W., Yuan, B., Lu, S., Zhang, Q., Zeng, L., and Wang, Q.: A temporally and spatially resolved validation of emission inventories by measurements of ambient volatile organic compounds in Beijing, China, Atmos. Chem. Phys., 14, 5871-5891, doi:10.5194/acp-14-5871-2014, 2014.

Warneke, C., McKeen, S. A., de Gouw, J. A., Goldan, P. D., Kuster, W. C., Holloway, J. S., Williams, E. J., Lerner, B. M., Parrish, D. D., Trainer, M., Fehsenfeld, F. C., Kato, S., Atlas, E. L., Baker, A., and Blake, D. R.: Determination of urban volatile organic compound emission ratios and comparison with an emissions database, J. Geophys. Res., 112, D10S47, doi:10.1029/2006JD007930, 2007.

Warneke, C., de Gouw, J. A., Holloway, J. S., Peischl, J., Ryerson, T. B., Atlas, E., Blake, D., Trainer, M., and Parrish, D. D.: Multiyear trends in volatile organic compounds in Los Angeles, California: Five decades of decreasing emissions, J. Geophys. Res., 117, D00V17, doi:10.1029/2012JD017899, 2012.

Watson, J. G., Chow, J. C., and Fujita, E. M.: Review of volatile organic compound source apportionment by chemical mass balance, Atmos. Environ., 35, 567-1584, 2001. 